\title{
Рейтинг факторов недревесной продукции леса Бугульминско-Белебеевской возвышенности Башкирии
}

Хисамов Р.Р., Мазуркин П.М., Рахматуллина И.Р.

Введение. Бугульминско-Белебеевская возвышенность в пределах Республики Башкортостан занимает западную приподнятую окраину республики и является одним из наиболее промышленно развитых, густонаселенных и лесодефицитных районов (рис. 1). По лесорастительному районированию территория отнесена к лесостепной зоне и лесостепному району Европейской части Российской Федерации. Общая площадь лесного фонда 314,0 тыс. га. (Лесохозяйственные регламенты, 2008).

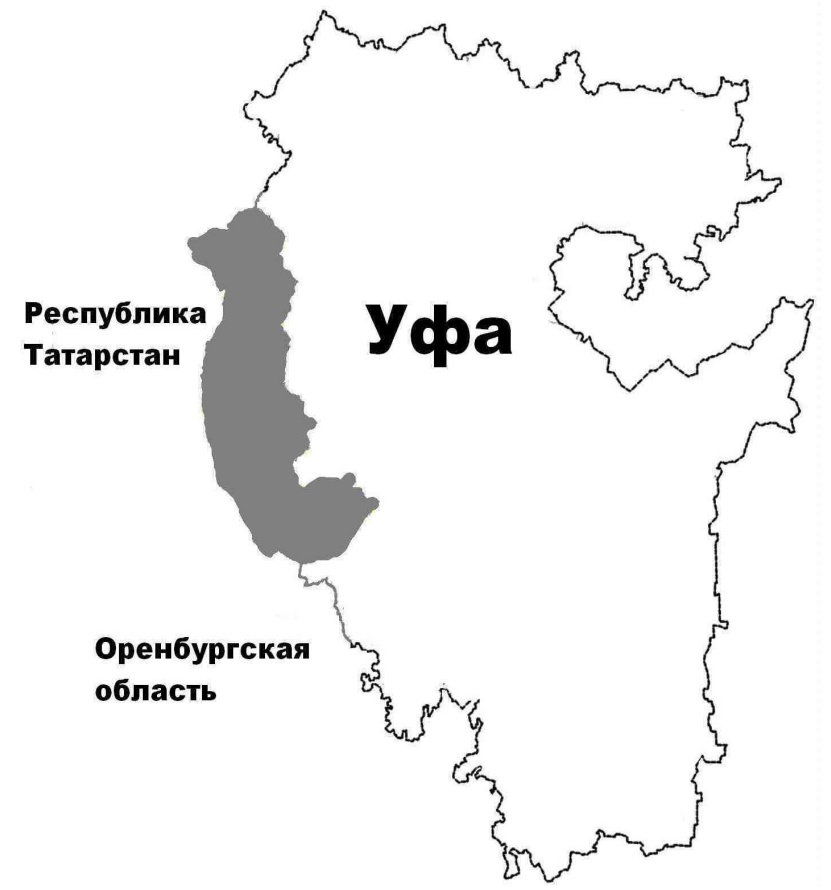

Рисунок 1. Бугульминско-Белебеевская возвышенность в пределах территории Республики Башкортостан

Для анализа заготовки и использования недревесной продукции леса были проанализированы следующие показатели: заготовка дикорастущего плодово-ягодного и лекарственного сырья; объемы заготовок сена на лесных сенокосных угодьях; лесное пчеловодство - объем медосбора с пасек, количество пчелосемей на пасеках. Исходный материал для работы выбирался из годовых отчетов лесничеств за 8 лет (2006-2013 гг.) [6, 7].

Статистическое моделирование. Вначале рассматриваются ранговые распределения значений у каждого фактора. Это дает два рейтинга:

a) районов по заготовке недревесной продукции леса;

б) добротности измерений по

каждому измеренному фактору [1].

Второй рейтинг позволяет оценивать качество измерений по каждому фактору и тем самым принять решения о совершенствовании существующих способов (методик) и устройств (приборов и оборудования).

Факторный анализ в общем случае проводится в четыре этапа:

1) выявление закономерностей рангового распределения по факторам;

2) выявление биотехнических закономерностей бинарных отношений между учитываемыми факторами;

3) рейтинг учтенных факторов по строкам (факторы как влияющие переменные) и столбцам (факторы как зависимые показатели) по общей корреляционной матрице;

4) рейтинг бинарных отношений по коэффициенту корреляции.

Второй этап подробно показан в публикациях [1-5]. В данной статье покажем методику по третьему этапу факторного анализа. 
Из-за периода времени за 8 лет динамики показателей были определены средние значения из данных таблицы 1 и таблицы 2 (всего 17 факторов) по 7 районам. Факторный анализ [1-5] нами проведен с применением детерминированной общей закономерности в виде суммы двух биотехнических законов

$$
y_{m}=y_{m 1}+y_{m 2}, y_{m 1}=a_{1} x^{a_{2}} \exp \left(-a_{3} x^{a_{4}}\right), y_{m 2}=a_{5} x^{a_{6}} \exp \left(-a_{7} x^{a_{8}}\right),
$$

где $y_{m}$ - тренд показателя, $x$ - объясняющая переменная, $a_{1} \ldots a_{8}$ - параметры модели (1), получаемые в CurveExpert (URL: http://www.curveexpert.net/).

Для выявления волновых членов дополнительно к тренду (1) необходимо множество из не менее 20 районов, то есть в дальнейшем придется рассматривать все муниципалитеты Башкирии, включая и города.

Исходные данные. Табличные данные для статистического моделирования [6] даны в таблице 1 и таблице 2.

Таблица 1

Распределение земель по районам на Бугульминско-Белебеевской возвышенности по категориям земель, тыс.га

\begin{tabular}{|c|c|c|c|c|c|c|c|c|c|}
\hline \multirow[b]{2}{*}{ Район } & \multirow[b]{2}{*}{\begin{tabular}{|c|} 
Общая \\
площадь \\
$S$
\end{tabular}} & \multirow{2}{*}{$\begin{array}{c}\text { Земли сельско- } \\
\text { хозяйственного } \\
\text { назначения } \\
S_{c x y}\end{array}$} & \multicolumn{6}{|c|}{ Земли лесного фонда } & \multirow[b]{2}{*}{$\begin{array}{c}\text { Прочие } \\
\text { земли } \\
S_{n p}\end{array}$} \\
\hline & & & \begin{tabular}{|c|} 
лесопок- \\
рытые \\
$S_{л n}$
\end{tabular} & \begin{tabular}{|c} 
pe- \\
дины \\
$S_{p}$, га
\end{tabular} \mid & $\begin{array}{c}\text { вы- } \\
\text { рубки } \\
S_{в}, \text { га }\end{array}$ & \begin{tabular}{|c|} 
прога- \\
лины \\
$S_{n p}$, \\
га
\end{tabular} & \begin{tabular}{|c|} 
сено- \\
косы \\
$S_{c}$
\end{tabular} & $\begin{array}{c}\text { паст- } \\
\text { бища } \\
S_{n}\end{array}$ & \\
\hline Бакал & & & & 39 & 1063 & 176 & 1.543 & & 11.490 \\
\hline Белебеев & & & & 65 & 889 & 279 & 1.328 & 1.046 & 8.937 \\
\hline Бижбуля & & & & 91 & 276 & 381 & 0.707 & 0.524 & 18.815 \\
\hline Ермекеев & 143.43 & 9.58 & 15.098 & 15 & 94 & 104 & 0.415 & 0.510 & 12.114 \\
\hline Миякг & & & & 104 & 265 & 214 & 1.195 & 0.636 & 14.396 \\
\hline Туйма & 235.78 & 136.77 & & 97 & 1186 & 524 & 2.669 & 1.545 & 24.577 \\
\hline Шаранский & 138.42 & 95.75 & 33.780 & 24 & 431 & 50 & 0.423 & 0.403 & 7.548 \\
\hline
\end{tabular}

Таблица 2

Показатели заготовки побочной продукции леса по районам на Бугульминско-Белебеевской возвышенности

\begin{tabular}{|c|c|c|c|c|c|c|c|c|}
\hline Район & \begin{tabular}{|c} 
Площадь \\
лесного \\
фонда \\
$S_{\text {ЛФ }}$, тыс. \\
га \\
\end{tabular} & $\begin{array}{c}\text { Площадь } \\
\text { липня- } \\
\text { ков } \\
S_{Л}, \text { тыс. га }\end{array}$ & $\begin{array}{c}\text { Объем рубок } \\
\text { ухода } \\
Q_{P y}, \text { тыс. }{ }^{3}\end{array}$ & $\begin{array}{c}\text { Объем } \\
\text { заготовки } \\
\text { плодов } \\
\text { и ягод } \\
Q_{\text {Пя }}, \text { ц } \\
\end{array}$ & $\begin{array}{c}\text { Объем } \\
\text { заготовки } \\
\text { лекарств. } \\
\text { сырья } \\
Q_{\text {ЛС }}, \text { ц }\end{array}$ & $\begin{array}{c}\text { Валовой } \\
\text { выход } \\
\text { сена } \\
Q_{C}, \text { т }\end{array}$ & $\begin{array}{l}\text { Объем } \\
\text { медо- } \\
\text { сбора } \\
Q_{M}, \text { т }\end{array}$ & $\begin{array}{c}\text { Кол-во } \\
\text { пчело } \\
\text { семей } \\
N_{\Pi C}, \\
\text { шт. }\end{array}$ \\
\hline Бакалинский & 63.894 & 19.120 & 29.9104 & 78.03 & 6.65 & 465.444 & 71.898 & 3121 \\
\hline Белебеевский & 68.816 & 11.859 & 15.3548 & 50.99 & 6.18 & 243.150 & 48.493 & 1901 \\
\hline Бижбулякский & 34.499 & 0.568 & 9.1416 & 21.50 & 4.61 & 138.300 & 30.379 & 1218 \\
\hline Ермекеевский & 21.738 & 13.072 & 6.7686 & 10.74 & 3.43 & 802.200 & 59.563 & 2006 \\
\hline Миякинский & 39.909 & 8.550 & 10.9030 & 20.50 & 3.76 & 265.311 & 43.479 & 1519 \\
\hline Туймазинский & 74.431 & 25.012 & 18.3007 & 66.40 & 10.50 & 325.767 & 46.477 & 2143 \\
\hline Шаранский & 35.118 & 8.440 & 10.9427 & 12.48 & 2.47 & 150.800 & 32.696 & 1378 \\
\hline
\end{tabular}

Методика анализа. Кроме ранговых распределений, в таблице 3 приведены коэффициенты корреляции ранговых и бинарных отношений между 17 факторами. При этом ранговые закономерности даны в диагоналях матрицы. Поэтому второй этап факторного анализа предполагается выполненным. 


\section{Корреляционная матрица и рейтинг факторов}

\begin{tabular}{|c|c|c|c|c|c|c|c|c|c|c|}
\hline \multirow{3}{*}{$\begin{array}{c}\text { Факторы } \\
\text { как объясняющие } \\
\text { переменные } x\end{array}$} & \multicolumn{10}{|c|}{ Факторы как показатели $y$} \\
\hline & $S$ & $S_{c x y}$ & $S_{\text {ЛФ }}$, & $S_{л n}$ & $S_{p}$ & $S_{B}$ & $S_{n p}$ & $S_{c}$ & $S_{n}$ & $S_{n p}$ \\
\hline & & т. га & т. га & га & га & га & га & га & га & га \\
\hline Ілощадь p & 0,97280 &, 7830 & 0,60300 & 0,5709 & 0,8891 & 0,50830 & 0,9359 & 0,8146 & 0,6852 & 20,8483 \\
\hline Ллощадь СХУ $S_{c x y}$, т. га &, 88170 & & & & & &,$/ 212$ & & & 40,8157 \\
\hline Ілощадь ЛФ $S_{\text {ЛФ }}$, т. га & 0,60080 &, 01 & מודוני & ד, נו, & 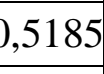 & $0668 \mathrm{~h}$ & 0,605 & 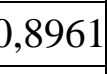 & 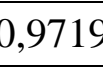 & 90,28 \\
\hline Песопокрытые $S_{n}$ &, 59120 & 0,0455 & 98860 & & & & 0,562 & 0,870 & 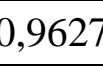 & 70,2500 \\
\hline Редины $S_{p}$, га & 0,90170 &, 000 & אונו & & &, 0700 &, 01 &, 00 & שודנ, & 60,7084 \\
\hline Зырубки $S_{\theta}$, га &, 51630 & 1242 & $0,9652 \alpha$ & 0,98 & & 0,9748 & 0,4696 & 020 & 0308 & 80,8485 \\
\hline Ірогалины $S_{n p}$, га & & & 5014 & & & , & (3) & ${ }_{1}$ & דונו, & 0,9064 \\
\hline Сенокосы $S_{c}$, га & 0,82880 & 2705 & 0,92600 & 0,88 & 0001 & $031 \mathrm{or}$ & 07685 & 0838 & $0077^{\prime}$ & 20,7850 \\
\hline Тастбища $S_{n}$, га & 0,84790 & & 95660 & & & ,93660 & 0,762 & ,966 & & ),7965 \\
\hline Прочие земли $S_{n p}$, га & 0,81320 & 0 &, $0<J u$ & 0,0 & 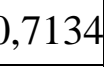 & 0,070 & 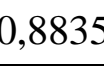 & 0 & וס & מדונס, \\
\hline Площадь липняков $S_{л}$, т. га & 0,77500 & 0,7405 & 78410 & 0,67 & & ארנקו, & 8723 & 891 &, 8860 & ,9220 \\
\hline Объем руб. ухода $Q_{P y}$, т. м ${ }^{3}$ & 0,55620 & & $081 \mathrm{oh}$ & 08 & & 0,9923 & 0,5695 & ש & 0,7120 & 0,2091 \\
\hline Объем плодов и ягод $Q_{\text {Пя }}$, ц & 0, & & 963 & 0,95 & 82 & ,957 & $0,70^{-}$ & 0,84 & 0,90 & 60,3655 \\
\hline Объем медосбора $Q_{\mu}$, т & 0,16360 & ),2943 &, 3972 & $0,72 \varepsilon$ & 607 & 0,7362 & 03712 & 475 &, 5387 & 70,2960 \\
\hline Объем лекар. сырья $Q_{\text {ЛС }}$, ц & 0,87940 & & 90030 & 0,87 & & $0155 \mathrm{~h}$ & 0,8098 & 054 & 0,9762 & 20,7041 \\
\hline Объем заготовки сена $Q_{C}$, т & 0,66500 &, 307 &, 85600 & 0,80 & 720 & 0,8002 & 0,495 & 880 & 81 & 0,2326 \\
\hline К-во пчелосемей $N_{\text {ПС }}$, шт. & 0,12790 &, 2587 &, 5483 & 0,52 & 2000 & p & 0,1021 & 0,700 & 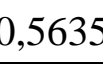 & 50,0838 \\
\hline Сумма коэфф. корр. $\sum r$ & 11,9385 & 8,1617 & $13,4531 \mid 1$ & 13,492 & 1,8206 & 13,7373 & 11,4976 & 13,812 & 13,8923 & 310,050 \\
\hline Рейтинг показателей $I_{y}$ & 13 & 17 & 8 & 7 & 3 & 5 & 14 & 4 & 2 & 16 \\
\hline
\end{tabular}

\section{Корреляционная матрица и рейтинг факторов}

\begin{tabular}{|c|c|c|c|c|c|c|c|c|c|}
\hline \multirow{2}{*}{$\begin{array}{c}\text { Факторы } \\
\text { как объясняющие } \\
\text { переменные } x\end{array}$} & \multicolumn{7}{|c|}{ Факторы как показатели $y$} & \multirow{2}{*}{$\begin{array}{c}\text { Сумма } \\
\sum r\end{array}$} & \multirow{2}{*}{$\begin{array}{c}\text { Место } \\
I_{x}\end{array}$} \\
\hline & $\begin{array}{r}S_{Л}, \\
\text { т. га } \\
\end{array}$ & $\begin{array}{l}Q_{P Y}, \\
\text { T. }{ }^{3} \\
\end{array}$ & $\begin{array}{c}Q_{\text {ПЯ }}, \\
\text { ц } \\
\end{array}$ & $\begin{array}{c}Q_{\mu}, \\
\mathrm{T}\end{array}$ & $\begin{array}{c}Q_{\text {ЛС }}, \\
\text { Ц }\end{array}$ & $\begin{array}{c}Q_{C}, \\
\mathrm{~T}\end{array}$ & $\begin{array}{c}N_{\Pi C}, \\
\text { Шт. }\end{array}$ & & \\
\hline Площадь района $S$, т. га & 0,2633 & 30,3637 & 0,5528 & 0,0322 & 0,7702 & 0,3422 & 20,2738 & 10,2093 & 15 \\
\hline Площадь СХУ $S_{c x y}$, т. га & 0,9606 & 50,7090 & 0,837 & 0,9040 & 0,801 &, 679 & 70,9105 & 13,5439 & 3 \\
\hline Площадь ЛФ $S_{Л \Phi}$, т. га & 0,7655 & 50,7472 & h 0116 & 9601 & $h 8090$ & 09736 & 50,9012 & 12,9772 & 8 \\
\hline Лесопокрытые $S_{л n}$, га & 0,8637 & 0,9037 & 0,91 &, 907 &, 92 & 0,9658 & 30,8740 & 13,4898 & 5 \\
\hline Редины $S_{p}$, га & 0,1250 & 0,7750 & 0,735 & 0,428 & , & 0,9352 & 20,2893 & 11,5002 & 14 \\
\hline Вырубки $S_{\theta}$, га & 0,9317 & 70,8334 & 0,9900 & 0,9530 & 0,9006 & 0,1482 & 20,9766 & 12,6595 & 10 \\
\hline Прогалины $S_{n p}$, га & 0,7669 & 0,1552 & $h 005$ & 1,10 & ),83 &, 6068 & 30,0167 & 11,7591 & 12 \\
\hline Сенокосы $S_{c}$, га & 0,9997 & 70,9880 & 0,9753 & 0,7653 & 0,9574 & 0,5898 & 30,9243 & 14,5419 & 2 \\
\hline Пастбища $S_{n}$, га & 0,8231 & 0,8080 & 0,9392 & 0,6232 & 0,9750 & 0,0016 & 50,7056 & 13,0623 & 7 \\
\hline Прочие земли $S_{n p}$, га & 0,7784 & 0,0269 & 0,2924 & 0,8013 & 0,7245 & 0,6603 & 30,6824 & 11,6880 & 13 \\
\hline Площадь липняков $S_{J}$, т. га & 0,9676 & 50,9440 & 0,8788 & 0,9678 & 0,9230 & 0,9891 & 0,9894 & 14,6691 & 1 \\
\hline
\end{tabular}




\begin{tabular}{|c|c|c|c|c|c|c|c|c|c|}
\hline \multirow{2}{*}{$\begin{array}{c}\text { Факторы } \\
\text { как объясняющие } \\
\text { переменные } x\end{array}$} & \multicolumn{7}{|c|}{ Факторы как показатели $y$} & \multirow[b]{2}{*}{$\begin{array}{l}\text { Сумма } \\
\sum r\end{array}$} & \multirow[b]{2}{*}{$\begin{array}{c}\text { Место } \\
I_{x}\end{array}$} \\
\hline & $\begin{array}{r}S_{Л}, \\
\text { т. га } \\
\end{array}$ & $\begin{array}{l}Q_{P Y}, \\
\text { T. }{ }^{3} \\
\end{array}$ & $\begin{array}{c}Q_{\text {ПЯ }}, \\
\text { ц } \\
\end{array}$ & $\begin{array}{c}Q_{M}, \\
\mathrm{~T}\end{array}$ & \begin{tabular}{|c|}
$Q_{\text {ЛС }}$, \\
$ц$ \\
\end{tabular} & $\begin{array}{c}Q_{C}, \\
\mathrm{~T}\end{array}$ & $\begin{array}{c}N_{\text {ПС }}, \\
\text { Шт. }\end{array}$ & & \\
\hline Объем рубок ухода $Q_{P y}$, т. м ${ }^{3}$ & 0,7160 & 0,9956 & 60770 & h7417 & 700 & 40868 & 0,8969 & 12,9292 & 9 \\
\hline Объем плодов и ягод $Q_{\text {Пя }}$, ц & 0,9558 & 30,9531 & 0,9854 & 0,7786 & 0.8617 & 0,0061 & 0,9404 & 13,5004 & 4 \\
\hline Объем медосбора $Q_{m}, \mathrm{~T}$ & 0,6952 & 7701 & h 5760 & 09873 & h1037 & 0746 & 0,9416 & 9,9163 & 16 \\
\hline Объем лекарств. сырья $Q_{Л C}$, ц & 0,787 & $50,71 \varepsilon$ & 0,99 & 0,46 & T & 0,017 &, 9304 & 13,1837 & 6 \\
\hline Объем заготовки сена $Q_{C}$, т & 0,8385 & 50,7889 & 68680 & 0,9246 & 7180 & 0,9973 & 0,8668 & 12,5779 & 11 \\
\hline Кол-во пчелосемей $N_{\Pi C}$, шт. & 0,8913 & 30,8773 & 0,7948 & 0,93 & 61 & 0,65 & 0,9879 & 9,4321 & 17 \\
\hline Сумма коэфф. корр. $\sum r$ & 13,1298 & 12,3166 & 14,121 & 12,9344 & 13,6395 & 10,5343 & 13,1078 & 211,6399 & - \\
\hline Рейтинг показателей $I_{y}$ & 9 & 12 & 1 & 11 & 6 & 15 & 10 & - & \\
\hline
\end{tabular}

В таблице 3 дополнительно к корреляционной матрице показан рейтинг ранговых и бинарных отношений между факторами из таблиц 1 и 2. Для выявления рейтинга факторов как влияющих переменных суммировании коэффициентов корреляции выполняют по строкам, а для рейтинга факторов как зависимых показателей - по столбцам. Затем рейтинговые места расставляют по убыванию суммы коэффициентов корреляции монарных и бинарных отношений.

Коэффициент коррелятивной вариации [1-5] множества факторов физического объекта исследования (в общем случае), то есть биологического, химического, технологического, социально-экономического и пр., равен отношению общей суммы коэффициентов корреляции к квадрату от количества факторов.

В нашем примере коэффициент коррелятивной вариации соответственно будет равен 211,6399 / $17^{2}=211,6399 / 289=0,7323$. Это высокий показатель функциональной связности всей системы территорий и лесного фонда Бугульминско-Белебеевской возвышенности по категориям земельного кадастра и заготовки побочной продукции леса.

Этот критерий применяется при сравнении различных объектов исследования. При этом вид изучаемой системы не влияет на указанный критерий верификации, а коррелятивная вариация полностью зависит от внутренних свойств системы.

В таблице 3 даны два рейтинга по убыванию суммы коэффициентов корреляции факторных отношений: во-первых, факторы как влияющие переменные; во-вторых, факторы как показатели или зависимые переменные.

На первом месте как влияющая переменная находится площадь липняков и поэтому липняки становятся системообразующей данную территорию физической величиной. На втором месте оказалась площадь сенокосов, а на третьем - площадь сельскохозяйственных угодий. А как показатель на первом месте оказался объем плодов и ягод. На втором месте - площадь пастбищ и на третьем - площадь редин в лесных массивах.

Из 17 факторов примем предел отсечения из группы факторов наиболее слабых по месту 10. Тогда из множества можно будет исключить факторы:

1) прочие земли (как переменная 13, а как показатель 16 место); 
2) площадь района (соответственно 15 и 13 места);

3) прогалины леса (12 и 14 места);

4) объем заготовки сена (11 и 15 места).

Тогда вместо 17 факторов в дальнейших измерениях можно будет применять группу только из 13 показателей.

Корреляционная матрица. Она показана в таблице 4. В ней удалены диагональные клетки по ранговым распределениям.

Таблица 4

Корреляционная матрица бинарных отношений факторов

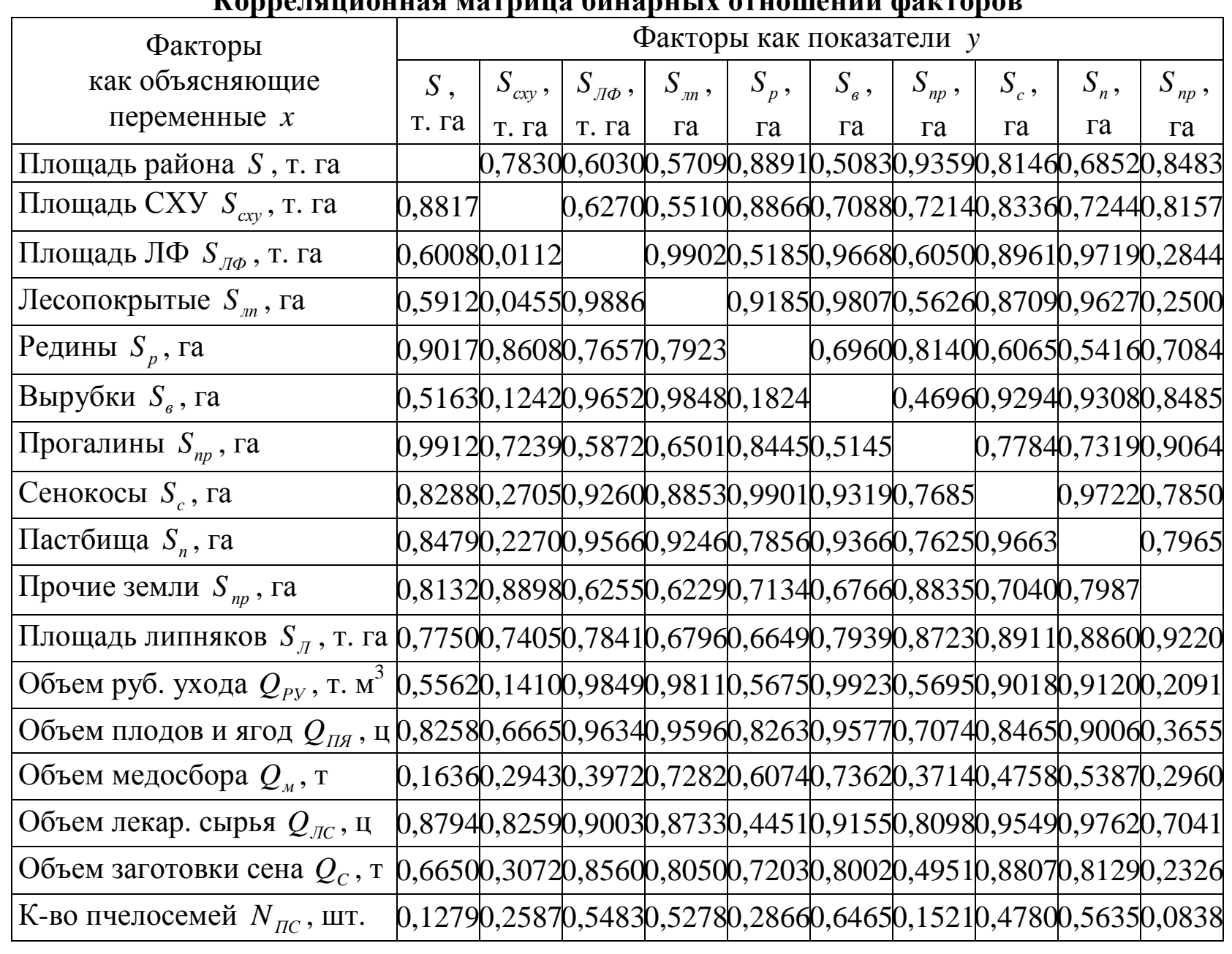

Продолжение табл. 4

Корреляционная матрица бинарных отношений факторов

\begin{tabular}{|c|c|c|c|c|c|c|c|}
\hline \multirow{2}{*}{$\begin{array}{c}\text { Факторы } \\
\text { как объясняющие } \\
\text { переменные } x\end{array}$} & \multicolumn{7}{|c|}{ Факторы как показатели $y$} \\
\hline & $\begin{array}{c}S_{J}, \\
\text { т. га }\end{array}$ & $\begin{array}{l}Q_{P V}, \\
\text { T. }{ }^{3}\end{array}$ & $\begin{array}{c}Q_{\text {Пя }}, \\
\text { ц }\end{array}$ & $\begin{array}{c}Q_{M}, \\
\mathrm{~T}\end{array}$ & $\begin{array}{c}Q_{\text {ЛС }}, \\
ц\end{array}$ & $\begin{array}{c}Q_{C}, \\
\mathrm{~T}\end{array}$ & $\begin{array}{c}N_{\text {ПC }}, \\
\text { шт. }\end{array}$ \\
\hline Площадь района $S$, т. га & 0,2633 & 0,3637 & 0,5528 & 0,0322 & 0,7702 & 0,3422 & 0,2738 \\
\hline Площадь СХУ $S_{c x y}$, т. га & 0,9606 & 0,7090 & 0,8371 & 0,9040 & 0,8011 & 0,6797 & 0,9105 \\
\hline Площадь ЛФ $S_{Л \Phi}$, т. га & 0,7655 & 0,7472 & 0,9116 & 0,9601 & 0,8990 & 0,9736 & 0,9012 \\
\hline Лесопокрытые $S_{л n}$, га & 0,8637 & 0,9037 & 0,9191 & 0,9070 & 0,9200 & 0,9658 & 0,8740 \\
\hline Редины $S_{p}$, га & 0,1250 & 0,7750 & 0,7354 & 0,4288 & 0,5507 & 0,9352 & 0,2893 \\
\hline Вырубки $S_{\theta}$, га & 0,9317 & 0,8334 & 0,9900 & 0,9530 & 0,9006 & 0,1482 & 0,9766 \\
\hline Прогалины $S_{n p}$, га & 0,7669 & 0,1552 & 0,8958 & 0,7607 & 0,8319 & 0,6068 & 0,0167 \\
\hline
\end{tabular}




\begin{tabular}{|c|c|c|c|c|c|c|c|}
\hline \multirow{2}{*}{$\begin{array}{c}\text { Факторы } \\
\text { как объясняющие } \\
\text { переменные } x\end{array}$} & \multicolumn{7}{|c|}{ Факторы как показатели $y$} \\
\hline & $\begin{array}{c}S_{J}, \\
\text { т. га }\end{array}$ & $\begin{array}{l}Q_{P y}, \\
\text { T. } \mathrm{M}^{3}\end{array}$ & $\begin{array}{c}Q_{\text {ПЯ }}, \\
\text { ц } \\
\end{array}$ & $\begin{array}{c}Q_{\mu}, \\
\mathrm{T}\end{array}$ & $\begin{array}{c}Q_{\text {ЛС }}, \\
ц\end{array}$ & $\begin{array}{c}Q_{C}, \\
\mathrm{~T}\end{array}$ & $\begin{array}{c}N_{\text {ПС }}, \\
\text { шт. }\end{array}$ \\
\hline Сенокосы $S_{c}$, га & 0,9997 & 0,9880 & 0,9753 & 0,7653 & 0,9574 & 0,5898 & 0,9243 \\
\hline Пастбища $S_{n}$, га & 0,8231 & 0,8080 & 0,9392 & 0,6232 & 0,9750 & 0,0016 & 0,7056 \\
\hline Прочие земли $S_{n p}$, га & 0,7784 & 0,0269 & 0,2924 & 0,8013 & 0,7245 & 0,6603 & 0,6824 \\
\hline Площадь липняков $S_{Л}$, т. га & & 0,9440 & 0,8788 & 0,9678 & 0,9230 & 0,9891 & 0,9894 \\
\hline Объем рубок ухода $Q_{P y}$, т. м $^{3}$ & 0,7160 & & 0,9772 & 0,7417 & 0,7996 & 0,9868 & 0,8969 \\
\hline Объем плодов и ягод $Q_{\text {Пя }}$, ц & 0,9558 & 0,9531 & & 0,7786 & 0,8617 & 0,0061 & 0,9404 \\
\hline Объем медосбора $Q_{\mu}$, т & 0,6952 & 0,7291 & 0,5760 & & 0,4037 & 0,9746 & 0,9416 \\
\hline Объем лекарств. сырья $Q_{Л C}$, ц & 0,7875 & 0,7185 & 0,9913 & 0,4617 & & 0,0174 & 0,9304 \\
\hline Объем заготовки сена $Q_{C}$, т & 0,8385 & 0,7889 & 0,8688 & 0,9246 & 0,7180 & & 0,8668 \\
\hline Кол-во пчелосемей $N_{\text {ПС }}$, шт. & 0,8913 & 0,8773 & 0,7948 & 0,9371 & 0,6107 & 0,6598 & \\
\hline
\end{tabular}

Анализ корреляционной матрицы. Закономерности можно оценить, если значения коэффициента корреляции всех бинарных отношений (по данным табл. 4) распределить по интервальной шкале (например, через одну десятую) допустимого уровня адекватности по коэффициенту корреляции.

Результат такого распределения дан в таблице 5.

Таблица 5

Характеристика выборки по уровням адекватности

\begin{tabular}{|c|c|c|c|}
\hline $\begin{array}{c}\text { Допусти- } \\
\text { мый } \\
\text { коэффици- } \\
\text { ент } \\
\text { корреля- } \\
\text { ции }[r]\end{array}$ & $\begin{array}{l}\text { Количе- } \\
\text { ство } \\
\text { формул } \\
\text { бинар- } \\
\text { ных } \\
\text { отноше- } \\
\text { ний }\end{array}$ & $\begin{array}{c}\text { Количе- } \\
\text { ство } \\
\text { остав- } \\
\text { шихся } \\
\text { строк } \\
\text { в матри- } \\
\text { це }\end{array}$ & $\begin{array}{c}\text { Количе- } \\
\text { ство } \\
\text { остав- } \\
\text { шихся } \\
\text { столб- } \\
\text { цов } \\
\text { матрицы }\end{array}$ \\
\hline 0 & 272 & 17 & 17 \\
\hline 0.1 & 263 & 17 & 17 \\
\hline 0.2 & 255 & 17 & 17 \\
\hline 0.3 & 240 & 17 & 17 \\
\hline 0.4 & 234 & 17 & 17 \\
\hline 0.5 & 226 & 17 & 17 \\
\hline 0.6 & 204 & 17 & 17 \\
\hline 0.7 & 180 & 17 & 17 \\
\hline 0.8 & 132 & 17 & 17 \\
\hline 0.9 & 79 & 16 & 16 \\
\hline 0.95 & 42 & 12 & 14 \\
\hline 0.99 & 7 & 6 & 7 \\
\hline 0.9997 & 1 & 1 & 1 \\
\hline 1 & 0 & 0 & 0 \\
\hline
\end{tabular}

Количество формул определится из выражения $17 \times 17-17=272$. Допустимый коэффициент корреляции показывает правую границу интервальной шкалы адекватности при условии «не меньше» или $\geq$.

Задаваясь допустимым значением $[r]$, можно оценить необходимый в факторном анализе уровень достоверности всего исследования. Нулевой коэффициент корреляции образуется при вычислении средней арифметической величины.

В этом случае многие проводят поверхностный анализ, так как среднеарифметическое значение изучаемого фактора недостаточно отражает поведение семи районов Республики Башкортостан.

Таблица 5 отображает также закономерности динамики требований к адекватности проведенных измерений.

После идентификации получены следующие формулы для характеристики показателей по данным таблицы 5:

- количество формул (рис. 2) корреляционной матрицы от допустимого уровня адекватности по коэффициенту корреляции 


$$
N_{0}=272,54336 \exp \left(-0,25993[r]^{0,78869}\right)-210,77714[r]^{4,16825} ;
$$

- количество строк в корреляционной матрице (рис. 3)

$$
N_{\leftrightarrow}=17,05130 \exp (-0,010996[r])-16,01544[r]^{26,88391} ;
$$

- количество столбцов в корреляционной матрице (рис. 3)

$$
N_{\uparrow}=17,00684 \exp \left(-0,58002[r]^{21,72248}-9,17556[r]^{92,00251} .\right.
$$

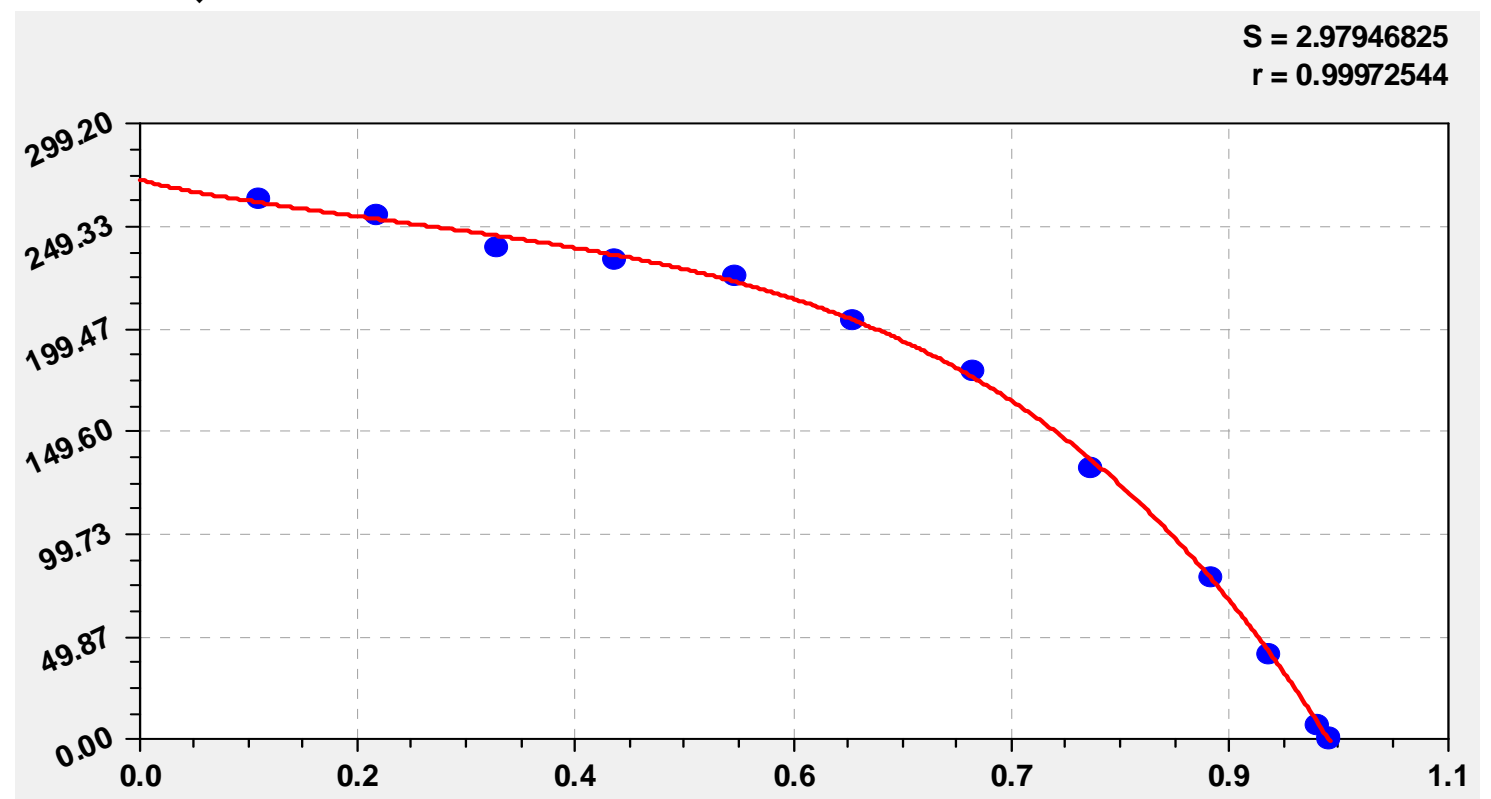

Рис. 2. График изменения количества формул (ордината) в зависимости от требований к допустимому уровню адекватности по коэффициенту корреляции (абсцисса) в корреляционной матрице бинарных отношений

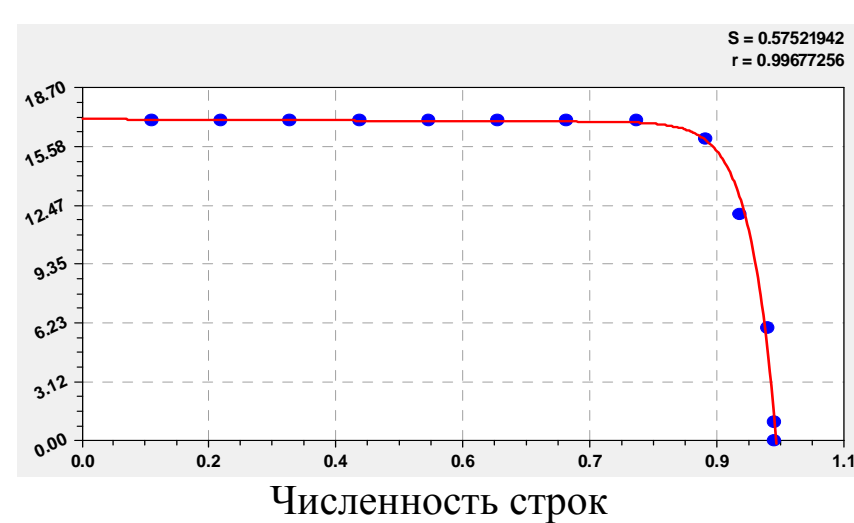

в корреляционной матрице бинаров

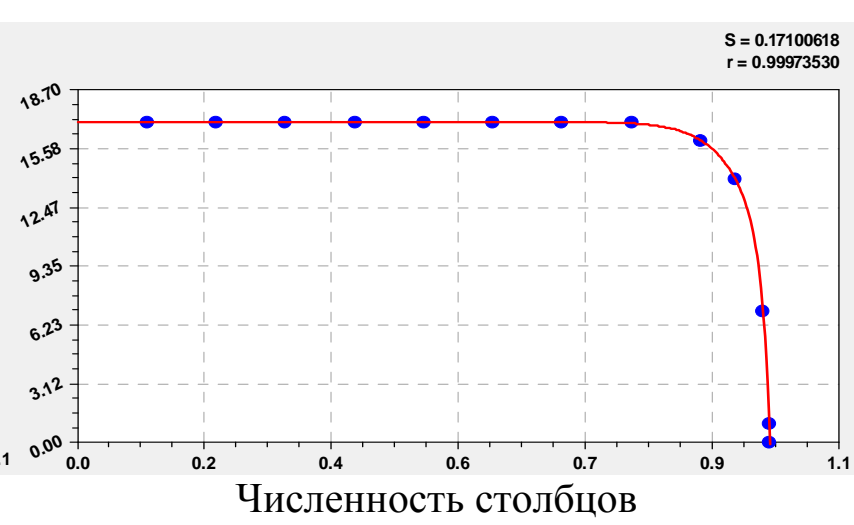

в корреляционной матрице бинаров

Рис. 3. Графики динамики численности строк и столбцов корреляционной матрицы в зависимости от требований к допустимому уровню адекватности

Из данных таблицы 5 и графиков на рисунке 3 видно, что снижение количества строк и столбцов корреляционной матрицы начинается при условии $R \geq 0,8$ или $[R]=0,8$. Поэтому все 17 показателей в динамике адекватности имеют уровень тесноты факторной связи не менее 0,8 .

Заключение. Наиболее высокий коэффициент корреляции 0,9997 получила закономерность изменения площади липняков в зависимости от площади сенокосов. В итоге статистическое моделирование позволяет выявить высоко- 
адекватные тренды взаимной зависимости площади компонент сельхозугодий по общей формуле (1).

Результаты моделирования позволяют надеяться, что, наконец-то, будут приниматься осознанные повороты в земельной политике и в технологии землепользования, причем как по категориям земельного кадастра, так и по отдельным элементам лесного фонда. Высокая функциональная связность между 17 факторами недревесного пользования к этому обязывает.

\section{Список литературы:}

1. Арзамасцев А.Д., Мазуркин П.М., Максимец Н.В. Факторный анализ сельскохозяйственного производства. Йошкар-Ола: МарГТУ, 2009. 388 с.

2. Мазуркин П.М. Решение 23-ой проблемы Гильберта // Междисциплинарные исследования в области математического моделирования и информатики. Матер. 3-й научно-прак. internet-конф. Ульяновск: SIMJET, 2014. C 269-277.

3. Мазуркин П.М., Долгих М.В. Компонентное равновесие и устойчивость древостоя. Йошкар-Ола: МарГТУ, 2011. 164 с.

4. Мазуркин П. М., Михайлова С.И. Территориальное экологическое равновесие $=$ Territprial ecological balance: аналит. обзор; Учреждение Рос. акад. наук Гос. публич. науч.-техн. б-ка Сиб. отд-ния РАН. Новосибирск: ГПНТБ СО РАН, 2010. 430 с. (Сер. Экология. Вып. 94).

5. Мазуркин П.М., Степкина Е.А. Экологическое равновесие древостоя. М.: Изд-во «Академия естествознания», 2009. 240 с.

6. Хисамов Р.Р. Хозяйственно-ценный фитоценоз в защитных лесных насаждениях на агроландшафтах Белебеевской возвышенности Республики Башкортостан / Хисамов Р.Р., Рахматуллина И.Р., Рахматуллин 3.3., Хасанов Ф.Ф. // Материалы международной научно-практической конференции «Сберегающие (биологическое) земледелие в современном сельском хозяйстве». Уфа: Гилем, Башк.энцикл., 2014. 244 с.

7. Хисамов Р.Р., Кулагин А.А. Биологические ресурсы Республики Башкортостан: недревесные ресурсы леса. Уфа: Изд-во БГПУ, 2014. 292 с. 